\title{
Brown Thrasher Nest on Corn Binder
}

\section{By Dr. STUART HOUSTON}
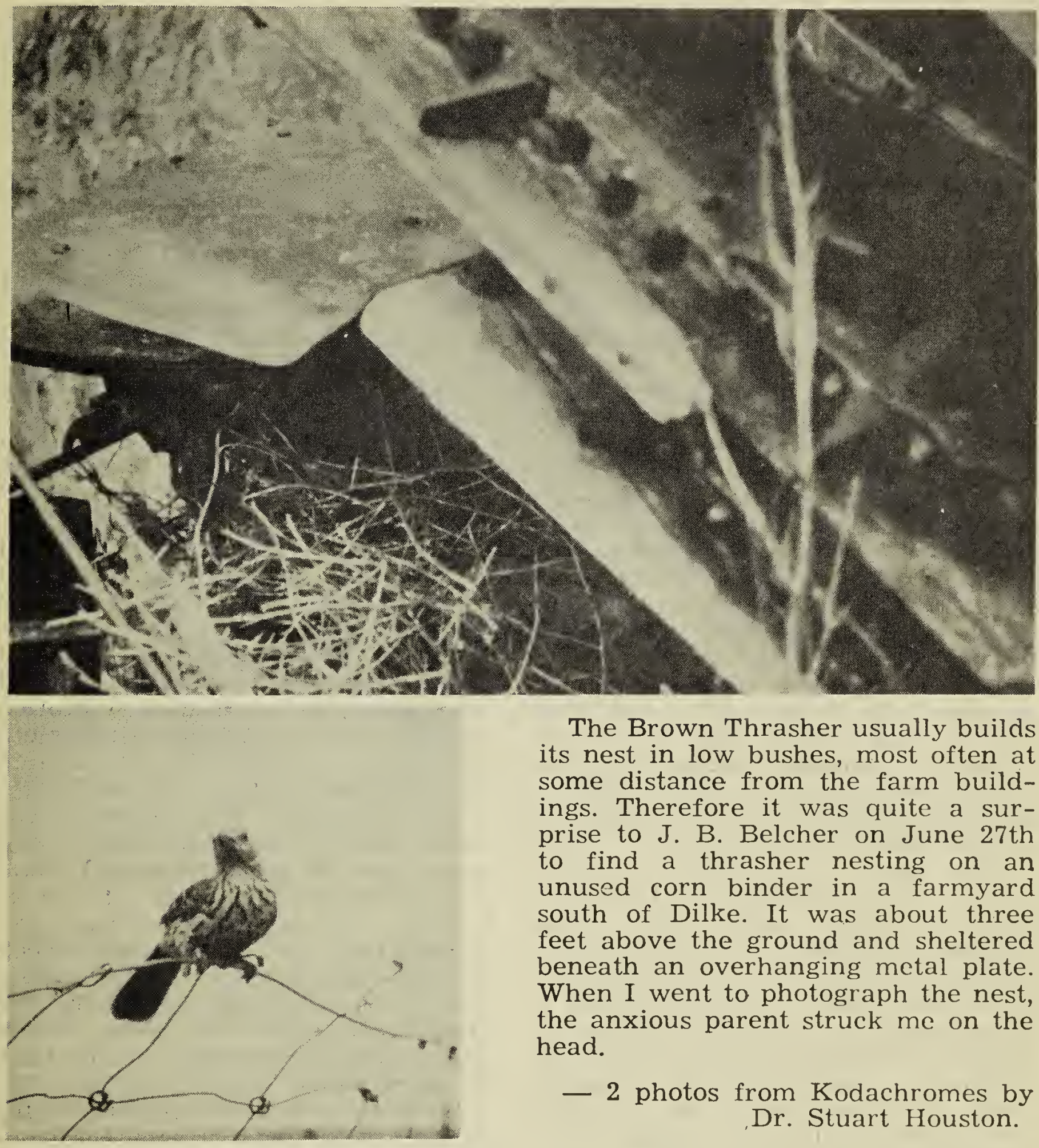

The Brown Thrasher usually builds its nest in low bushes, most often at some distance from the farm buildings. Therefore it was quite a surprise to J. B. Belcher on June 27th to find a thrasher nesting on an unused corn binder in a farmyard south of Dilke. It was about three feet above the ground and sheltered beneath an overhanging metal plate. When I went to photograph the nest, the anxious parent struck me on the head.

- 2 photos from Kodachromes by Dr. Stuart Houston.

\section{Interesting Acquaintances}

\section{By HUGH McLAUGHLIN, Lewvan, Sask.}

There are birds which nest in colonies but they do not predominate on the prairies. I am farming a quarter section with a creek running through it, and in the summer of 1952 I took particular note of nesting birds. Those actually found were two Kildeer, one Willit, one Marbled Godwit, one Bobolink, three ducks, one Ground Owl, several Red-winged Blackbirds and one Crow. It would be safe to presume two or three Meadowlarks nest there also, as they are a very prominent bird. I would like to be able to add the Whitewinged Blackbird or the Lark Bunting, but cannot. Although we usually see a few of these birds every sum- 
mer, I have only found one nesting in my lifetime.

The noisy Kildeer seems to hatch her eggs quite successfully, and her relations, the Godwit and Willit likewise. It was quite a satisfaction to see the Willet chase Mr. Crow, the long pointed bill of the Willet apparently commanding respect, and, when the crow had been safely driven away - the triumphant return to the still nesting female. These birds are not much disturbed by tractors and faithfully return to nests or just sit still, unless pressed too closely.

But the duck nests in the open field, and once I noticed that one egg had an experimental nick in it five minutes after the mother was flushed. I hoped she would return and cover the eggs. Futile clods were hurled at the crows and it was quite a coincidence, a few minutes later, to see one of the crows battling with a mouse. I have only noticed that effort this once. The crow had some difficulty in dispatching the mouse - but eventually its pinching beak weakened its prey and the mouse was carried away. However, the next day every single duck egg had been broken. A hundred yards from the crow's nest - close to the water another Mallard hatched her eggs to a safe finish.

The crows would chase a hawk, with vocal indignation, that approached their nest, while Redwinged Blackbirds or com mon blackbirds would gang up on both crow and hawk, and lead them a miserable life until they retreated. I could.not quite forgive the crow and I played a dastardly trick. I waited until the young crows were hatched and then, taking advantage of a mother crow's bravery, sent a bullet into the nest from below. Mother crow died instantly, and the young - all in different stages of growth - were hauled down and dispatched. Whether it is the right thing to do, I do not know. Still the idea persists that crows were not originally prairic birds, owing to the lack of trees for nesting sites, and that ducks were unmolested before - so if sides have to be taken, it's the ducks for me.

On the same farm land, I saw a peaceful threcsome in a two-foot triangle; a Godwit and a Teal on the bank of the creek and a Coot, close by in the water. There they sat in the sun as though conversing. On another occasion, while fixing a fence, son David and I heard a loud roaring sound - something quite startling. Two hundred feet away a Teal was in a frantic power dive, and in hot pursuit, straight down, a hawk. The duck dove straight into the water with a splash at a terrific speed, while the hawk veered away from the surface, inches behind.

Two deer presented quite a sight one early morning as they were startled from the creek - to bound away over the fence and out of sight. On another occasion a lone deer came bounding into the quarter as I worked. It scemed to lurch over two fences with a last bit of energy and was obviously tired. It disappeared over the creek bank and I ran the tractor close for a peek. There it stood in midstream drinking, and the picture is indelibly sketched on my mind - I do not have the opportunity to see a deer drinking there every day - and I could not help trying to piece some forgotten words together: "As the hart panteth after the water brooks, so panteth my soul after Thee, O God."

The deer lay down under some buck brush, some distance away. Some time in the afternoon I could not resist another look. In some tension I walked into the brush, expecting to see a bounding deer. Soon a slight commotion, four feet away, swung my attention, and there "on guard position" was a skunk, whose nap I had interrupted. I went back to work.

Some times it is a muskrat pushing its way up or down stream, occasionally a mink who sends the muskrat scurrying, or a family of tiny shrews under an upturned board, or a bold and curious weasel who seems to want to sce you as much as you to see him, or a pudgy badger, caught away from home who can't be forced into the water, can't run away very fast, and who turns and faces you on the stream's cdge and snorts defiance - but would much prefer to go about his business of excavating.

They all become interesting - the acquaintance is satisfying, and it all adds to the harvest of the season. 